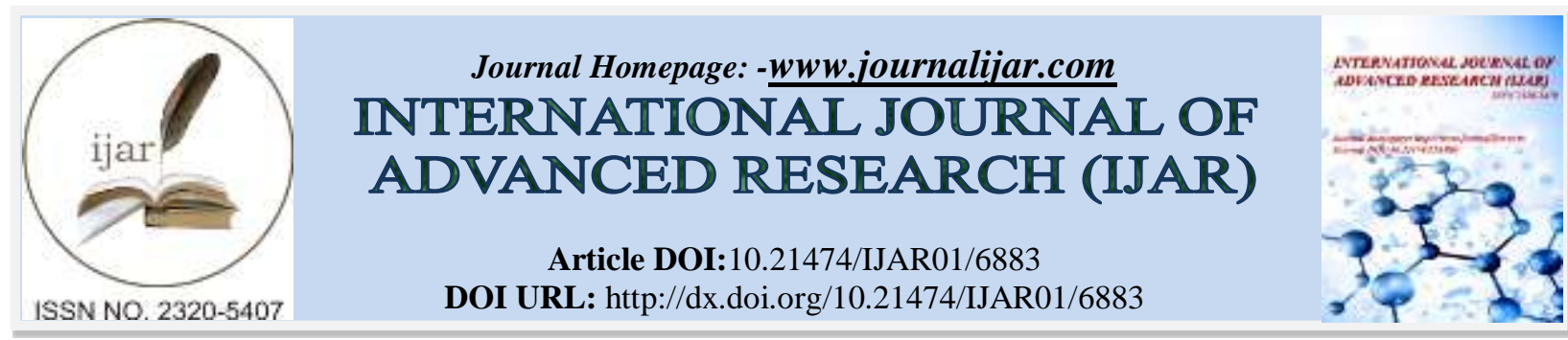

RESEARCH ARTICLE

\title{
TO STUDY THE PERFORMANCE M3O GRADE CONCRETE DUE TO CHANGE IN PH VALUE OF MIXING AND CURING WATER.
}

\author{
Rajendra Prasad Singh ${ }^{1}$, K. Sunil kumar ${ }^{2}$, Ch. E. Vijay Kumar ${ }^{3}$ and B. Teja ${ }^{3}$. \\ 1. Asst. Professor, Dept. of Civil Engineering, MVGR College of Engineering, Vizianagaram, India. \\ 2. M.Tech. Student, MVGR College of Engineering, Vizianagaram, India. \\ 3. Graduate student, MVGR College of Engineering, Vizianagaram, India.
}

\section{Manuscript Info}

Manuscript History

Received: 08 February 2018

Final Accepted: 10 March 2018

Published: April 2018

\begin{abstract}
The quality of water used in mixing and curing the concrete is the major factor which influences the strength of the concrete, As per IS 456-2000, it specifies the quality of water to be within the limiting range. The effect of variation of water quality on strength of concrete is not known. In the present work, the effect of $\mathrm{pH}$ value of the water used in mixing and curing of concrete in strength of concrete is studied by considering $\mathrm{pH}$ values as $\mathrm{pH} 4, \mathrm{pH} 7, \mathrm{pH} 9$ and $\mathrm{pH} 12$.

This work was carried out for a mix of M30 grade concrete to study effect of the water of different $\mathrm{pH}$ values used in mixing and curing on the strength development of concrete at 7,28,56 and 90 days. From the results it is observed that concrete casted and cured using $\mathrm{pH} 9$ shows the greater strength when compared with other $\mathrm{pH}$ values, $\mathrm{pH} 4$ gives out the least of the strength. There was no homogeneity effect on concrete by changing in the $\mathrm{pH}$ values. Little change was seen on the concrete. when the compressive testing was done $\mathrm{pH}-4$ was taking the load up to the crushing of concrete. There should be changing of water for the $\mathrm{pH}-4, \mathrm{pH}-9$ and $\mathrm{pH}-12$.
\end{abstract}

Copy Right, IJAR, 2018,. All rights reserved.

\section{Introduction:-}

Concrete is one of the most commonly used construction materials in the world. Concrete has relatively high compressive strength, but lower tensile strength. However, when exposed to severe environments its strength can significantly decline due to degradation of concrete. Cement used in concrete is a mixture of complex mineral compounds. The reaction of these with water leads to setting and hardening of cement. The Tricalcium Silicate and Dicalcium Silicate are the most important compounds responsible for strength. Together they constitute 70 to 80 percent of cement. The average $\mathrm{C} 3 \mathrm{~S}$ content in modern cement is about 45 percent and that $\mathrm{C} 2 \mathrm{~S}$ is about 25 percent. The sum of the contents of $\mathrm{C} 3 \mathrm{~A}$ and $\mathrm{C} 4 \mathrm{AF}$ has decreased slightly in modern cement. the hydrates rather slowly. The initial setting is attributed to hydration reactions. The C2S (Dicalcium Silicate) phase the reactions of C3A, C3 S and C,.AF (lea, 1956).

Impurities in water may interact with the of the cement and may adversely affect the strength of the concrete (Neville,1970). The chemical constituents present in water may participate in the chemical reactions and thus affect the setting, Hardening and strength development of concrete. 


\section{Material And Specifications:-}

The water cement ratio is selected based on the desired compressive strength or the expected exposure conditions. The amount of mixing water is based on the maximum aggregate size and the desired slump range. The aggregate proportions are selected to provide for an economical mixture with the desired workability and finish ability characteristics. A different type of Portland cement allows some tailoring of strength grain characteristics or for additional resistance to chemical attach.

In practice mix proportions vary depending on the properties of the individual ingredients and on the desired properties of the concrete in service details of some actual mixes used in the past.

\section{Cement:-}

Ordinary Portland cement of 53 grade was used.

$\begin{array}{ccl}\text { The specific gravity } & - & 3.14 \\ \text { Normal consistency } & - & 32 \% \\ \text { initial setting time } & - & 35 \text { Minutes } \\ \text { and final setting time } & - & 580 \text { Minutes }\end{array}$

Fine aggregate:-

The fine aggregate were tested and are as per IS: 383-1970.

Specific gravity Fineness modulus

Zone

Moisture content Water absorption -
2.60

$-\quad 2.34$

$-\quad$ III

$0.20 \%$

$1.15 \%$

Coarse aggregate:-

Coarse aggregate was procured from local market. The specific gravity, moisture content, water absorption, crushing value and impact value of coarse aggregate were $2.744,0.10 \%, 0.55 \%, 23.76 \%$ and $15.875 \%$ respectively. All the physical and mechanical properties of coarse aggregate were as per the standard limit of IS: 383-1970.

\section{Chemicals used for maintaining desired pH:-}

1. Sodium hydroxide

2. Hydrogen chloride

3. Ammonia Solution

The chemicals procured were manufactured by E. Merck India Limited were used in this research work.

Preparation of Alkaline water (for Ph-12):-

1. Take 1 litre of deionised water.

2. Approximately $40 \mathrm{gm}$ of sodium hydroxide $(\mathrm{NaOH})$ was added in 1 litre of normal water and mixed thoroughly to obtain alkaline solution.

3. Finally, a digital $\mathrm{pH}$ meter was used to measure the $\mathrm{pH}$ value of the solution and which obtained the solution of $\mathrm{pH} 12$.

Preparation of Alkaline water (for Ph-9):-

4. Take 1 litre of deionised water.

5. Approximately $22 \mathrm{ml}$ of Ammonia solution $\left(\mathrm{NH}_{3}\right)$ was added in 1 litre of normal water and mixed thoroughly to obtain alkaline solution.

6. Finally, a digital $\mathrm{pH}$ meter was used to measure the $\mathrm{pH}$ value of the solution and which obtained the solution of $\mathrm{pH} 9.0$.

Preparation of Acidic water (for Ph-4):-

7. Take 1 litre of deionised water. 
8. Approximately $2 \mathrm{ml}$ of hydrogen chloride $(\mathrm{HCl})$ was added in 1 liter of normal water and mixed thoroughly to obtain acidic solution.

9. Finally, a digital $\mathrm{pH}$ meter was used to measure the $\mathrm{pH}$ value of the solution and which obtained the solution of $\mathrm{pH} 4$.

\section{Methodology:-}

The M30 grade of concrete is proportioned as per the mix design and the water to be used for mixing of water is made with different $\mathrm{pH}$ of waters. The four different mixes P-4, P-7, P-9 and P-12 were prepared for four different $\mathrm{pH}$ values $(\mathrm{pH}-4, \mathrm{pH}-7, \mathrm{pH}-9$ and $\mathrm{pH}-12)$ in water.

The mix design is as shown in table I

Table I:-mix design

\begin{tabular}{|c|c|c|}
\hline Mix & w/c ratio & Mix proportion \\
\hline P-4 & 0.5 & $1: 2.12: 2.92$ \\
\hline P-7 & 0.5 & $1: 2.12: 2.92$ \\
\hline P-9 & 0.5 & $1: 2.12: 2.92$ \\
\hline P-12 & 0.5 & $1: 2.12: 2.92$ \\
\hline
\end{tabular}

Table II:-The quantity of material

\begin{tabular}{|c|c|c|c|}
\hline Water & Cement & Fine aggregate & $\begin{array}{c}\text { Coarse } \\
\text { Aggregate }\end{array}$ \\
\hline $187 \mathrm{~kg} / \mathrm{m}^{3}$ & $370 \mathrm{~kg} / \mathrm{m}^{3}$ & $787 \mathrm{~kg} / \mathrm{m}^{3}$ & $1082 \mathrm{~kg} / \mathrm{m}^{3}$ \\
\hline 0.5 & 1 & 2.12 & 2.92 \\
\hline
\end{tabular}

\section{Methods of curing:-}

Curing is the process in which the rate and extent of loss of moisture from concrete to make hydration process of cement is done. Proper curing will maintain temperature of concrete in its early ages, as this directly affects the rate of hydration of cement and eventually the strength gain of concrete.

In the present work the effect of acids and basses mixing in water on the strength and durability of hardened concrete is studied. An experimental work is carried out in following curing conditions: -

1. Normal water curing

2. Alkaline curing

3. Acid curing

\section{Normal water Curing:-}

Portable water is generally considered satisfactory for curing. The samples were tested for 7days, 28days, 56days and 90 days of proper curing.

\section{Alkaline and Acidic curing:-}

The solution used for alkaline and acidic curing of concrete samples was prepared using $\mathrm{NaOH}, \mathrm{NH}_{3}$ and $\mathrm{HCL}$ which was dissolved in water to obtain solutions with $\mathrm{pH}$ of $12,9,4$. The concrete samples were tested after 7 days, 28 days, 56 days and 90 days of proper alkaline and acidic curing. There curing was done in different tubs with different $\mathrm{pH}$ values in each tubs. There should be change in water for changing of $\mathrm{pH}$ values in tubs. Every day check the $\mathrm{pH}$ values in tubs. 


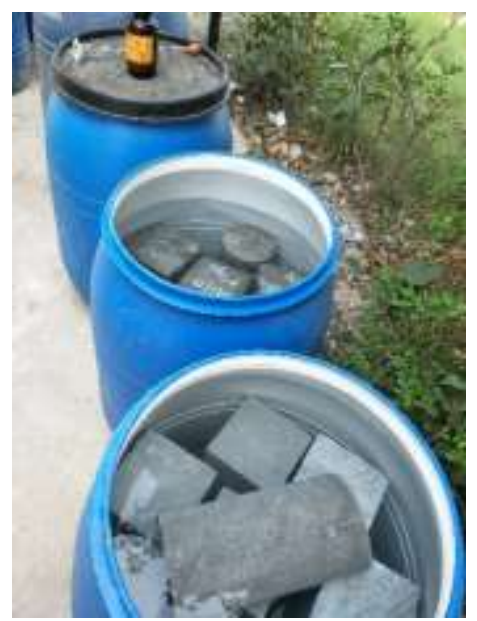

Figure showing the curing process
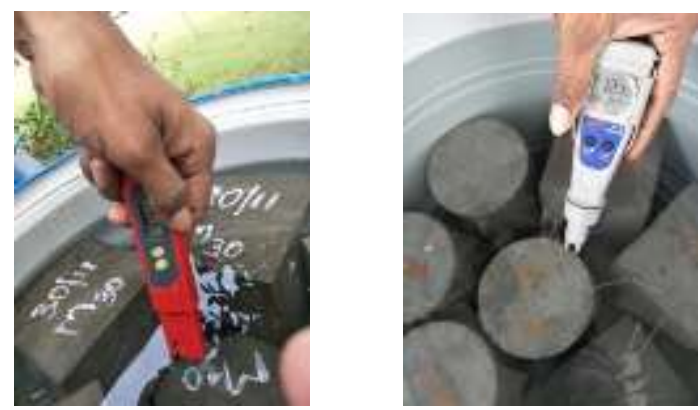

Figure showing the monitoring of $\mathrm{pH}$ of curing water

\section{Results And Discussion:-}

Compressive strength of concrete is measured in two different ways:

1. Cube compressive strength (Destructive) test and

2. Non Destructive test method.

Compressive strength test is done in compressive testing machine for M30 Grade concrete after 7, 28, 56 and 90days curing.

Schmidt Rebound Hammer test is done in the laboratory. Test is done by placing the concrete cube in compression testing machine and by applying 30\% load required to that of the full strength of the specimen. The test was done for 28days only.

Ultrasonic Pulse velocity test was done to find the homogeneity of the concrete for every change $\mathrm{pH}$ values in the concrete. The test was done for 28 days only.

Table III:-Compressive strengths of the Mixes

\begin{tabular}{|l|c|c|c|c|}
\hline \multirow{2}{*}{ Mix } & \multicolumn{4}{|c|}{ Compressive strength(MPa) } \\
\cline { 2 - 5 } & $\mathbf{7}$ days & $\mathbf{2 8}$ days & $\begin{array}{c}\mathbf{5 6} \\
\text { days }\end{array}$ & $\begin{array}{c}\mathbf{9 0} \\
\text { days }\end{array}$ \\
\hline P-4 & 14.5 & 23.53 & 28.4 & 28.167 \\
\hline P-7 & 18.7 & 37.93 & 37.5 & 38.5 \\
\hline P-9 & 32.3 & 42.83 & 39.51 & 37.4 \\
\hline P-12 & 14.5 & 23.53 & 28.4 & 28.167 \\
\hline
\end{tabular}




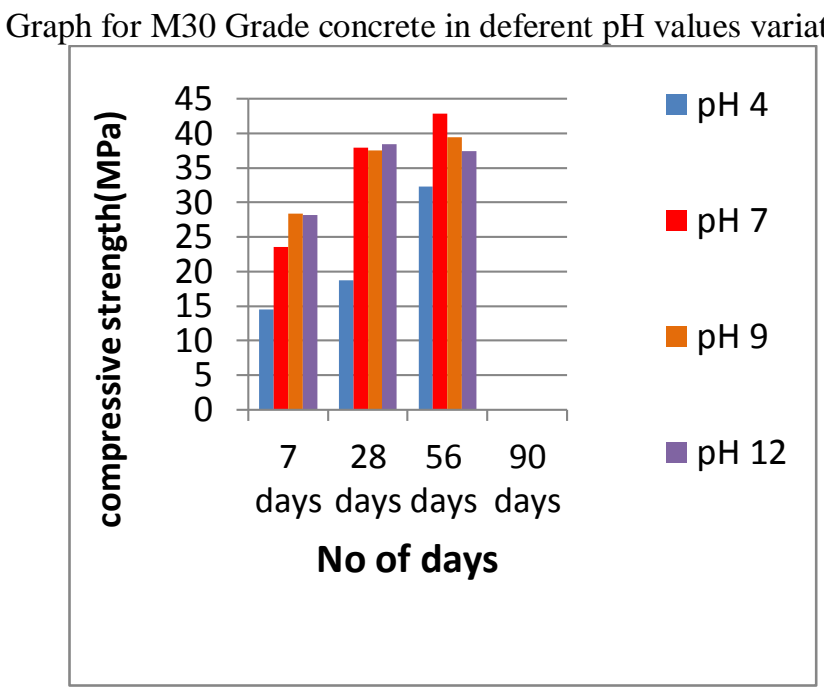

The cube compressive strength of M30 Grade concrete is observed that, for $\mathrm{pH} 4$ and $\mathrm{pH} 12$ are decreased. Further, the 90 days strength is observed to be reduced for all $\mathrm{pH}$ values except for $\mathrm{pH} 7$ (which is normal water).

Table IV:-Rebound number compressive strength value for 28 days

\begin{tabular}{|c|c|}
\hline $\mathbf{p H}$ values & $\begin{array}{c}\text { Average rebound number compressive strength values } \\
\text { (MPa) }\end{array}$ \\
\hline $\mathrm{pH}-4$ & 29.82 \\
\hline $\mathrm{pH}-7$ & 31.66 \\
\hline $\mathrm{pH}-9$ & 25.6 \\
\hline $\mathrm{pH}-12$ & 25.46 \\
\hline
\end{tabular}

The rebound hammer test for of $\mathrm{M} 30$ Grade concrete is observed that, the rebound compressive strength is reduced to all the $\mathrm{pH}$ of water except for $\mathrm{pH} 7$, from which it can be concluded that the concrete has got surface disintegrated.

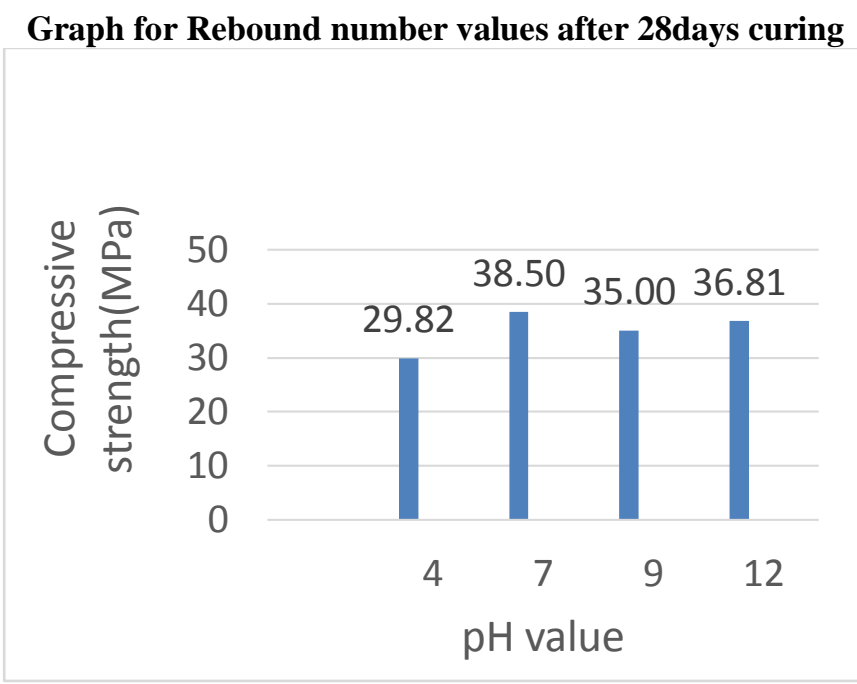

Table IV:-Ultrasonic pulse velocity test after 28 days curing.

\begin{tabular}{|c|ccc|l|}
\hline pH values & $\begin{array}{l}\text { Ultrasonic pulse velocity test values for } \\
\mathbf{2 8 d a y s}(\mathbf{k m} / \mathbf{s})\end{array}$ & Concrete Quality \\
\hline $\mathrm{pH}-4$ & 4.8 & Very good to Excellent \\
\hline
\end{tabular}




\begin{tabular}{|c|c|l|}
\hline $\mathrm{pH}-7$ & 5.01 & Very good to Excellent \\
\hline $\mathrm{pH}-9$ & 4.85 & Very good to Excellent \\
\hline $\mathrm{pH}-12$ & 4.53 & Very good to Excellent \\
\hline
\end{tabular}

The UPV test for of M30 Grade concrete is observed that, the pulse velocity is reduced to all the pH of water except for $\mathrm{pH} 7$, from which it can be concluded that the concrete has lost its integrity.

Penfei Haung, Yiwang Bao, Yan Yao (2005):- Influence of $\mathrm{HCl}$ corrosion on the mechanical properties of concrete. Cement and Concrete Research 35 584-589.

E. Arunakanthi, H. Sudarsana Rao and I.V. Ramana Reddy:-

"Effect of hydrochloric acid inmixing and curing water on strength of high-performance metakaolin concrete". International Journal of Applied Engineering and Technology, 2012 Vol. 2 (2) April-June.

Mr. K. J. Kucche, Dr. S. S. Jamkar and, Dr.P.A.Sadgir " Quality of Water for Making Concrete : A Review of Literature" International Journal of Scientific and Research Publications, Volume 5, Issue 1, January 2015.

Sonu Pal, M. K. Mishra, V. Pandey:-

"Effects of Alkaline curing on the properties of polyester fibre reinforced concrete" International Journal of Civil Engineering and Technology (IJCIET)

Volume 7, Issue 4, July-August 2016. 